\title{
Rodzina w polskich doświadczeniach wojennych. Sytuacje elementarne
}

Narratorka: A moi wnukowie tė̇ wiedza o tym, bo też, prawda, czasami, jak jest rocznica, to córka mnie prosi, żeby im opowiedzieć, zreszta najstarszy Bartek to już się bardzo tym interesuje. No i to u niego byto takie pytanie: Dlaczego, to byto takie śmieszne pytanie (-) wtedy miat chyba jakieś 6 lat, jak się spytat mojej córki: «Dlaczego Hitler strzelat do babci?» (Pani Ewa, s.16).

Poniższy tekst jest fragmentem opracowania opartego na wywiadach narracyjnych pochodzących z zespołowych badań Biografia a tożsamość narodowa i dotyczy życia rodzinnego narratorów. Podstawowe ustalenia tego opracowania mówią o relacyjnym, interakcyjnym charakterze kategorii nazywanych rolami rodzinnymi (matka, brat, żona, córka, stryj itd.), będących podstawą powiązań rodzinnych. Tworzą one to, co nazywamy domem - z jakimś wyposażeniem materialnym i kulturalnym, zapewniającym poczucie codziennego oparcia i bezpieczeństwa życiowego w znanych i ustalonych granicach. Wojna jest dla domu doświadczeniem negatywnym - zagraża, utrudnia, ogranicza, wreszcie uniemożliwia codzienną dynamikę interakcji rodzinnych. Wojenne doświadczanie domu i wspólnoty rodzinnej, a zarazem jej zagrożenia - już choćby wiedza o możliwości rozłąki i utraty - oraz cierpienie wywołane ich destrukcją (wyobrażoną lub rzeczywistą) powodują specjalne działania uczestników wspólnot podtrzymujące zakłóconą przez wojnę dynamikę interakcji oraz pozwalające chronić domowe wyposażenie rodzin.

W narracjach znajdujemy zatem liczne przykłady pracy czy walki w trosce o zachowanie tożsamości $\mathrm{w}$ rolach rodzinnych $\mathrm{w}$ obliczu ich zagrożenia $\mathrm{z}$ zewnątrz, rzadziej przykłady załamania i bezradności, opisywane jako przejściowe. Systematyzacja podejmowanej na przekór wojnie pracy narratorów nad tożsamością rodzinną oparta została przeze mnie na przypadkach uznanych za typowe dla personalnie zróżnicowanych nuklearnych układów rodzinnych: mąż - żona, syn - ojciec, matka - syn, córka - matka, córka - ojciec, siostra - brat. Różnice w tych układach zależą od fazy cyklu rodzinnego przypadającej na okres wojny, a także od cech rodzin wyznaczających ramy ich „społecznych światów” (Silverman 1993). 
Podjęłam także kwestię miejsca ról rodzinnych w pełnych konfiguracjach tożsamości narratorów i członków ich rodzin, zwłaszcza w związku z ich ewentualnym zaangażowaniem $\mathrm{w}$ walkę $\mathrm{z}$ okupantem, jako podstawowym wyzwaniem wojennym Polaków. Wojenna trajektoryjność losu rodziny zderza się tu z biograficznym planem działania podejmowanym przez narratora ze względu na motywy inne niż rodzinne. Specyficznym wariantem polskich autobiografii jest całkowita harmonia postaw wszystkich zaangażowanych w ruch oporu członków rodziny walka o wolność jest traktowana jako sprawa dla nich pierwszoplanowa.

Szczególnie interesujące są narracje odzwierciedlające nakładanie się w jednej perspektywie biograficznej wspólnoty rodzinnej, narodowej i państwowej czy regionalnej narratora, wówczas, gdy historia powstaje w ramach powiązań rodzinnych. Daje to narratorowi poczucie naturalności i zakorzenienia, można by rzec, zadomowienia w historii.

Opracowanie moje koresponduje z artykułem Piotra Łukasiewicza Funkcje domu w okresie okupacji niemieckiej (1989). Lecz zagadnieniem pierwszoplanowym jest tu rodzina w znaczeniu ściśle socjologicznym, to jest - za Florianem Znanieckim - interakcyjny personalny układ społeczny będący rdzeniem domu.

Trzeba jeszcze dodać, że wojenne losy własne opowiadane przez narratorów po przeszło pół wieku są żywą historią, to jest czasem ciągle obecnym, ponieważ narratorzy występują $\mathrm{w}$ nich $\mathrm{w}$ rolach rodzinnych. W ten sposób uobecniają oni los swoich ojców, braci, matek i sióstr - ludzi, którym wraz z nimi cierpienie przyniosła pół wieku temu II wojna światowa. Taką samą rolę spełniają na przykład stowarzyszenia pod znamienną nazwą Rodziny Katyńskie, najściślej łącząc czasy wojenne ze współczesnością.

*

W tym miejscu pragnę się skupić wyłącznie na kwestii traktowania przez narratorów powiązań rodzinnych jako elementarnej sytuacji społecznej, traktowania rodziny jako podstawowej identyfikacji człowieka. Jest to zarazem kwestia ujmowania rodziny jako środka wyrażania sensu istnienia innych wspólnot jako ramy porządkowania świata i układu odniesienia dla ocen, norm i sądów. W kategoriach pojęcia tożsamości byłaby to fundamentalna, obiektywna identyczność osób z rodziną (jak z płcią i rasą) na mocy kodu pierwotności, to jest kodowania kolektywnej tożsamości, gdy kod skoncentrowany jest na pokrewieństwie (Eisenstadt, Giesen 1993).

Przedstawię zatem i zinterpretuję zawarte w materiale sytuacje rodzinne, które można uznać za elementarne sytuacje życiowe. Stanowią one w gruncie rzeczy płaszczyznę określania znaczenia podstawowych słów używanych zarówno w zebranych opowiadaniach, jak i w całym moim opracowaniu. Prócz zebranych wywiadów wykorzystuję inne dane autobiograficzne. Na zakończenie poddam analizie wiersz Juliana Tuwima Matka. Modelowo niejako uwyraźnia on podstawowy sens związku matki i syna w tragicznych okolicznościach II wojny światowej. Trzeba przy tym zauważyć, że wydobycie socjologicznego znaczenia wypowiedzi 
Tuwima nie jest możliwe bez zacytowania wiersza w całości. Podobnie niezbędne byłoby w gruncie rzeczy przytoczenie i szczegółowe zinterpretowanie tych większych fragmentów narracji, w których zawarte są istotne aspekty jakościowo pojmowanych kategorii rodzinnych. Z uwagi na brak miejsca jest to niemożliwe. Jednak odwołując się do intuicji czytelników zwracam uwagę na zróżnicowane sytuacje, w których stosunki rodzinne stają się podstawowymi związkami między ludźmi.

W swojej analizie zamierzam pozostawać w kręgu socjologii uprawianej przez Andrzeja Tyszkę (zob. Tyszka 1993). Na marginesie warto jednak przypomnieć, że w ramach rozwijanej przez długie lata w PRL socjologii rodziny stosunki rodzinne nie były bynajmniej traktowane jako autonomiczne elementarne powiązania społeczne, lecz jako zjawisko pochodne względem struktury społecznej. Zbigniew Tyszka (1984) pisał na przykład, że określony system społeczny mikrostrukturalny i makrostrukturalny istniejący w danym okresie kreuje poszczególne kategorie rodzin w zależności od ich miejsca w strukturze społecznej. W ogromnej liczbie publikacji poświęconych rodzinie skupiano się na zależności cech i funkcji rodzin polskich od pozarodzinnych czynników społecznych. Te zależności, nie zaś problematyka rodziny jako takiej, podlegały badaniom empirycznym i teoretycznemu opracowaniu.

1.

Znane w refleksji socjologicznej od czasów Arystotelesa przekonanie o relacyjnym charakterze kategorii rodzinnych, czyli pogląd, że rodzina nie jest zbiorem osób, lecz układem osobowych stosunków, w żadnym innym socjologicznym materiale nie znajduje tak pełnego potwierdzenia jak w autobiografiach. Kategorie rodzinne zawierają oczywisty interakcyjny sens. Znaczy to, że mówiąc o swym ojcu, narratorka mówi o nim, jako jego córka, mówi zatem jednocześnie i o sobie w roli córki; mówiąc o swej siostrze narrator mówi o niej, jako jej brat, mówi zatem i o sobie. Biografie wojenne wzmagają jeszcze to odczucie.

$\mathrm{W}$ takim rozumieniu patriotyzm i śmierć brata jest zarazem elementem losu opowiadającej o tym siostry (,walczył na Wale Pomorskim i zginął... 19-letni chłopak. Ale on bardzo pragnął (((nie może mówić, szloch))) wyzwolić Polskę, bo jeszcze mam tutaj nawet listy z frontu, od tego młodszego"; Pani Kolińska, s. 4). Czekanie na powrót córki jest elementem losu matki („Krysiuniu, żebyś choć karteczkę zostawiła, kiedy wracasz... Córeczko, tak ciężko wyczekiwać..."; Wańkowicz 1991: 319).

Każdy opowiadający posługując się nazwami ról rodzinnych ujmuje zarazem losy własne oraz innego człowieka i sytuuje się wraz z nim w specyficznie wyodrębnionych wspólnotach życia (a osoba nazwana „rodzinnie” jest dla narratora osobą jedyną na świecie). Ze wspólnot tych mamy zatem „relację uczestniczącą”. Począwszy od pierwszych chwil narracji dowiadujemy się: „razem z rodzicami 
nas wysiedlili..." (Pani Czerwińska); ,ja też dzieci wysłałam i mamę wysłałam na wieś” (Sąsiadka); „byłam w domu, rodzeństwo miałam, jeszcze dwóch braci wtedy, mama mi zmarła” (Barbara S.); ,proszę pana, ojciec był legionistą, brał udział w kampanii wschodniej, proszę pana” (Bolesław K.); „mieszkałem wtedy jako kawaler z dwoma moimi siostrami" (Franciszek S.); ,siostra poszła na odpust (-) matka w strachu (-), no, ojciec powiada...” (Władek); „tutaj miałem znajomości, u rodziców, no i tu brat" (Alfred T.); „moja mama też nie pracowała, moi bracia” (Pani Krantówna); „my mieszkaliśmy w Łodzi, to znaczy ja z moimi rodzicami” (Janina P.); ,poszłam do domu, spytałam mamę” (Pani Ludka); ,powiedzmy, mój ojciec... stary legionista” (Halina W.); „śmierć stryja Józefa, ojciec...” (Pan A.), „mama, ojciec, babcia i brat i ja” (Pani z Oświęcimia); „ojciec mój” (Pani Teresa) itd.

Tego typu związki personalne oddają sytuację życiową relacjonowaną słuchającemu na początku opowiadania jako prezentacja siebie, bez poczucia konieczności dodatkowych objaśnień, jak gdyby na mocy zakładanego, oczywistego porozumienia. Można przypuszczać, że niektórzy narratorzy prezentując się poprzez związki rodzinne, mówią o nich głośno także do siebie samych. W jednym z wywiadów słuchający zaznaczył tę sytuację: „«Mogłaby Pani o tym opowiedzieć trochę? O swojej rodzinie, o tym, o». Narratorka: «O, tak» (((w zamyśleniu, jakby do siebie")))" (Pani Kolińska).

O tym, jak związek z mężem może być przez żonę odczuty jako wyjątkowa życiowa sytuacja, informuje epizod z Powstania Warszawskiego w opowiadaniu Haliny W.:

[...] to jeszcze może się wrócę. (-) I był moment, że trzeba było przebiec przez dziedziniec. No i ja z mężem mieliśmy przebiec. No i przede mną, nie, ja pierwsza przebiegłam, a za mną mój mąż miał... Tymczasem męża wyprzedził taki młody jakiś powstaniec. (-) I ten Niemiec strzelił. Ja byłam pewna, że to mojego męża zabił. Bo on miał przecież za mną... Od, od... Naraz stanęłam jak zdrętwiała. A mój mąż mówi: ja żyję, jestem, to nie ja! To... ja się dopiero odwróciłam. A ten młody człowiek, który dopiero co ze mną rozmawiał. Jakiś powstaniec. Więc to też było strasznym szokiem dla mnie... (Halina W., s. 11).

\section{2.}

Już pierwsze dni wojny, pełne chaosu i trwogi, zweryfikowały powiązania rodzinne jako najmniej podatne na destrukcję. W tłumie ludzi na drogach narratorzy znajdują się prawie zawsze z kimś z rodziny, co zresztą dodatkowo może przysparzać ciężkich przeżyć. Jednak osoby z rodziny w thumie obcych uciekinierów stanowią punkty oparcia porządkujące chaos (Janina P.). Ktoś z rodziny jest też zwykle punktem dotarcia do celu ucieczki lub miejscem powrotu, gdy dom własny uległ rozbiciu. Prawie zawsze też miejsce zamieszkania po wojnie wyznacza narratorowi wcześniejsza obecność kogoś z rodziny. Do wyjątków należy 
samotna matka z Kazachstanu, repatriantka, która w 1945 r. wybrała miejsce pobytu ze względu na leczenie synka. Lecz władze administracyjne Łodzi zezwoliły jej na pobyt $\mathrm{w}$ mieście tylko dlatego, że podała nieprawdziwą informację o tym, iż żyje tu ktoś z jej rodziny (Pani Romiluk).

Działania wojenne, a potem terror stosowany przez okupantów - to bezustanny czas zagrożeń dla związków rodzinnych. Zagrożenia owe różnicują się w zależności od miejsca zamieszkania narratorów, pozycji społecznej ich własnej lub rodziców, wieku narratorów, wiedzy o okupantach. Opanowanie zagrożenia, czyli zaradność dnia codziennego, w odniesieniu do takich wspólnot, jakimi są rodziny, to szczególna dialektyka obu wektorów biograficznych, to jest wektora zagrożenia i wektora zaradności. Należy podkreślić, iż jest to właśnie dialektyczna współgra, nie zaś sekwencje zagrożenia i zaradności. Jest to zatem z jednej strony zagrożenie, mimo podejmowania działań, aby dać sobie radę, oraz z drugiej strony - zaradność nie likwidująca zagrożeń w następnych dniach. Ta domowa dialektyka zagrożeń i dawania sobie rady, obecna zresztą w rodzinach niezależnie od okoliczności i wywołująca ambiwalentne uczucia w czasie wojny, miała miejsce w stopniu niezwykle nasilonym we wszystkich socjologicznie zróżnicowanych typach rodzin.

Oto początek wojny w relacji narratorki z Wilna:

[...] odprowadziłam męża na lotnisko w czasie mobilizacji, on szedł z ogólnej mobilizacji. Tego samego dnia (-) przemówienie do narodu prezydenta Mościckiego (-) o swoim mężu nic nie wiedziałam (-) w Czerwonym Krzyżu... i ja chodziłam codziennie pytałam, czy nie ma jakichś wiadomości właśnie od mojego męża. Nic! nic! bo różni napływali znajomi nawet, albo wiadomości o nich a tu nic. I raptem któregoś dnia zjawia się. (-) No i dopiero zaczęły się dla mnie kłopoty. Bo... parę nocy przenocował oczywiście, ale ciotka bała się okropnie trzymać kogoś niemeldowanego, a zameldować przy bolszewikach mowy nie było oficera z wojska. (-) I dopiero zaczęły się moje kłopoty z szukaniem noclegów codziennie u kogo innego. (-) I wtedy ja wszystkie swoje stosunki dziecinne - bo ja urodziłam się w Wilnie i wychowałam się w Wilnie - musiałam wykorzystać i przypominać sobie, chodziłam po ludziach i prosiłam, żeby przyjęli na jedną noc. To było straszne... (-) i tam do końca przechował się. A ja pamiętam te wszystkie, ile ja musiałam znosić upokorzeń i przykrości. I w ogóle ile musiałam wymyślać dzień w dzień do kogo by jeszcze pójść i prosić o ten nocleg (Pani Komańska, s. 4).

Sytuacja permanentnego stresu, często trwająca całe lata wojny, była przede wszystkim udziałem samotnych matek z małymi dziećmi: „Ach, proszę pana, bo nie ma nic straszniejszego, jak kiedy dziecko jest głodne i nie ma co mu dać jeść" (Czapski 1990: 319). Narratorzy, a częściej narratorki, podczas wojny będący dziećmi, podkreślają codzienny trud i niepokój swoich matek. Komentarzem na ten właśnie temat kończy się wywiad z panią Wiśniewską:

Bo uważałam i do tej pory zresztą uważam, czasami tak się zastanawiam, co musiała przeżywać moja mama właśnie w tym czasie kiedy wiedziała, że ma czworo 
dzieci, no i musi im właśnie zapewnić im to, nawet nie chodziło o to zapewnienie, tylko że jest świadoma tego, że o właśnie tak, te dzieci są w takich warunkach, prawda (-) więc ja uważałam, żebym ja nie musiała być w takiej sytuacji, że trzeba gdzieś uciekać już z dziećmi, już właśnie się o nie martwić czy też no właśnie martwić się, że jeden jest tu, drugi tam gdzieś na wojnie, już potem jako dorośli. (-) tak, że ten strach przed wojną, to mi pozostał do tej pory... (Pani Wiśniewska, s. 17).

Można powiedzieć, że tożsamość kobiet w rolach matek, także starszych sióstr „matkujących” młodszemu rodzeństwu, wystawiona w czasie wojny na wielką próbę, była też chyba motywem najusilniejszych zabiegów podejmowanych po to, by sprostać wyobrażonym wymogom. O tym, jak powszechne i jednorodne są modelowe wyobrażenia dotyczące tej roli, świadczy używanie słowa „matka” wobec obcej kobiety funkcjonującej właśnie jak matka. W kontakcie z osobą pełniącą ową rolę nawet dorosły mężczyzna przeżywa dziecięce szczęście biernego, ufnego poddania się jej opiece:

W silnej gorączce, na oddziale tyfusowym, niewiele pamiętam z pierwszych tygodni poza szeroką, dobrą, schyloną pod światło nad moim łóżkiem twarzą Niny Fiodorowny, starszej siostry oddziału. Wielu chorych i sióstr nazywało ją «mama». Miałem to poczucie bezwolne i szczęśliwe, że o mnie myślą, że mam prawo być zupełnie bierny, że nikt niczego ode mnie nie żąda poza połykaniem jakichś pigułek, lekarstw i poza mierzeniem gorączki (Czapski 1990: 296).

\section{3.}

Wartości rodzinne i narodowe współistnieją w wielu opowiadaniach. Na przykład w narracji Haliny W., która rezygnuje z udziału w konspiracji, ponieważ jest w ciąży i we wrześniu 1944 r. rodzi w Warszawie syna, przez żołnierzy AK nazywanego najmłodszym powstańcem. Powiązania rodzinne z okresu dzieciństwa są wskazywane zwłaszcza przy wyjaśnianiu własnego patriotyzmu. Kwestia ta jest przedmiotem oddzielnej części opracowania.

W tym miejscu należy odnotować obecny w materiale bardzo specyficzny narodowy i uniwersalny kontekst słowa „matka” odnoszący się do Niemców. W odróżnieniu od innych matek los matki niemieckiej obejmuje nie tylko uczestnictwo w cierpieniu jej dzieci, ale także współudział w ich zbrodni, a zatem poczucie winy i wstydu wobec innych narodów. Oto świadectwo narratora - więźnia obozu w Mauthausen, który był w miejscu dawnego obozu w końcu lat 80 . Wielkie wrażenie zrobił na nim pomnik matki Niemców. Utrwalił go na fotografii, a także zapisał słowa na nim wyryte. Narracja w tym fragmencie ma charakter uroczysty i osobisty, wyraźnie kontrastując z ironicznym tonem całego opowiadania, zawierającego przecież sceny niezwykle dramatyczne. Narrator uznaje pomnik zawstydzonej wobec narodów niemieckiej matki za przejmująco adekwatną alegorię zbrodniczych rezultatów wojny wywołanej i prowadzonej przez państwo niemieckie. Dodajmy, że narrator, przedwojenny absolwent Wydziału Prawa na 
Uniwersytecie Jagiellońskim, był do roku 1939 entuzjastą kultury niemieckiej jako najwyższej kultury w Europie.

Chciałbym tu panu jeszcze coś pokazać... (pokazuje przeźrocza z Mauthausen, jakie wykonał podczas zwiedzania obozu w końcu lat 80). Proszę pana, w obozie (-) jak się schodzi już tam na dół do kamieniołomów, już po oswobodzeniu, poszczególne narodowości postawiły swoje pomniki ((mówi to jakoś uroczyście)) Polacy, Żydzi itd. itd. To jest pomnik, proszę pana, postawiony przez Niemców (-) tam pisze tak, proszę pana: «O ty niemiecka matko która tu... ((płacze?))... siedzisz pełna wstydu i... i... tak jak twoje dzieci cię właśnie... cię wystawiły na ten pośpiech... tak właśnie ty tutaj stoisz». To jest... yy... z jakiegoś, proszę pana... ja mam to gdzieś tam przepisane, ale... Tak. I to jest, wie Pan, ogromnie przejmujący ten pomnik... Chociaż w ten sposób oni jakoś... czy niektórzy z nich potrafili... ((po 5-ciu linijkach rozmowy na inny temat znajduje się tekst)) «O Deutschland bleiche Mutter... Sie haben deine Söhne... jak cię twoi synowie tak urządzili» - tak po polsku powiedziawszy - «że ty siedzisz między narodami jako wyrzut albo strach»... To jest z Brechta, proszę Pana... (Pan Orlicz, s. 20-21).

Obecny w narracji pana Orlicza niemiecki symbol tragicznego macierzyństwa, który dziś świadczy wobec całego świata o latach wojny w jednym z najokrutniejszych miejsc kaźni II wojny światowej, na „ścieżce śmierci” do kamieniołomu w Mauthausen, personalizuje się, w prywatnym niejako wymiarze, w wywiadzie Władka K., chłopca wiejskiego, który w dniu wybuchu wojny miał 11 lat:

N: 44-ty rok (-) wszystkich Niemców, takich od 16-tu lat Niemczaków, pobrali do wojska! Tak, że u Niemców zostały, mało kto. Ta Niemka, która miała dziesięciu synów, ta, ta, ta, oczywiście, nasza sąsiadka, już czterech nie żyje! Wszystko ginie na froncie rosyjskim. Dostała od Hitlera krzyż zasługi za tyle synów, że wychowała, żeby zdobywali dla niemieckiego państwa ziemię, szmergła o podłogę i powiada: «na co mi ten krzyż, jak mi synowie nie żyją».

I: I to wyście wiedzieli, tak? (-)

N: No, oczywiście, opowiadała mi służąca, że ona to zrobiła (Władek K., s. 6).

Mowa tu o rodzinie Niemców z Wołynia osiedlonej wraz z innymi we wsi Władka K. w 1940 r. na miejsce wysiedlonych ze swych gospodarstw Polaków. Jak widać, będąca świadkiem zdarzenia w domu niemieckim służąca Polka uznała je za godne uwagi, opowiedziała sąsiadowi, ten zaś zrelacjonował je po pięćdziesięciu latach. Można powiedzieć, że obaj ci różniący się pod wieloma względami narratorzy dzielą się z badaczem wiedzą o dramatycznych czasach wojny, przejmując również perspektywę okupanta, za pośrednictwem przechowywanych w pamięci obrazów pogwałconego macierzyństwa.

Dobrym przykładem różnic w traktowaniu osoby spokrewnionej i obcej jest relacja z Oświęcimia. Narratorka mówi o wielkiej solidarności więźniarek Polek, 
wyrażającej się w dzieleniu się paczkami, życzliwych rozmowach itd. Opisuje też wyjątkowo ryzykowne i skuteczne działanie swej starszej kuzynki wówczas, gdy sama była umierająca. Na działanie takie nie zdobyła się żadna z wysoko pozytywnie przez nią ocenianych współwięźniarek. Podkreślając nadzwyczajne zabiegi kuzynki narratorka nie nazywa ich heroizmem. Takiego określenia nie używa zresztą żaden z narratorów w odniesieniu do trudu, często ponad siły, podejmowanego przez członków rodzin, aby zaradzić kłopotom, na jakie wojna naraża ich domy. (O swej matce jako bohaterce mówi jedynie p. Orlicz, w związku z ciężkim charakterem swego ojca, odnosząc to do czasów przedwojennych). Heroizm zwykle kojarzony jest z nadzwyczajnym, bezinteresownym działaniem nie na rzecz osób bliskich, lecz obcych,

Niewątpliwie trudniej jest zdobyć się na czyn heroiczny wobec obcego. Dlaczego jednak takiego samego działania wobec bliskich także nie nazwie się heroizmem? Być może dlatego, że nie jest ono uznawane za bezinteresowne. Pomagając dziecku matka pomaga sobie, gdyż w przeciwnym razie cierpiałaby wraz z dzieckiem. Oto jeszcze jeden wskaźnik powszechnego traktowania stosunków rodzinnych jako elementarnych powiązań naturalnych. Warto zauważyć, że role rodzinne, choć w czasie wojny mogą przynosić cierpienia, są w narracjach waloryzowane pozytywnie lub traktowane jako obiektywna konieczność życiowa.

Straszne było to miasto przed opuszczeniem jego przez Niemców, straszne. I na przykład wtedy moja stryjenka i moja babcia i moja siostra stryjeczna, ich dom, znaczy, straciły w ogóle dom, ich dom się spalił zupełnie - nie ich dom tylko dom, w którym one wynajmowały mieszkanie. Więc myśmy musiały się na przykład jeszcze wszystkim co miały podzielić, bo po prostu oni nie mieli no nic, zostali w ogóle bez niczego, bo był spalony zupełnie" - mówi pani Natalia (s. 17).

Wyrażenia podobne do: „myśmy musiały” w odniesieniu do świadczeń na rzecz członków rodziny będących w potrzebie, są w zebranych materiałach bardzo charakterystyczne jako argument podejmowanych działań. Najczęściej jednak opowiadanie o takich działaniach pozbawione jest specjalnego podawania motywów, na mocy porozumienia ze słuchającym, z użyciem konstrukcji „bo,”, „ale”, „no więc": „Taszczyłem ćwiartkę ziemniaków... jesienią... między innymi... bo wiele było takich zadań bo... ojciec no... był w Tomaszowie ale w domu były dwie siostry i matka. No więc od razu były wielkie trudności z zaopatrzeniem się w żywność" (Eligiusz K., s. 1).

\section{5.}

W wywiadach nie można prawie znaleźć, nawet epizodycznych, negatywnych przykładów z życia rodzinnego. Wyjątki od reguły, świadectwa o przejściowym załamaniu się ojców we wrześniu 1939 r., dowodzą raczej bezmiaru klęski wrześniowej. Interesujący z tego punktu widzenia jest przypadek pani Zofii z Wilna. Model odniesień rodzinnych jest tak silny, że decyzja o podjęciu indywidualnej 
drogi życiowej i opuszczenia w 1945 r. Wilna oraz pozostającej tam rodziny opatrzona jest rozbudowanym komentarzem. Komentarzem podwójnym - na użytek ciotek narratorki mających zastrzeżenia do niej w 1945 r. i na użytek słuchającego, po prawie pięćdziesięciu latach od tamtej decyzji.

Można domniemywać, że ewentualne ciemne strony losów rodzinnych narratorów są przemilczane, wyparte, potraktowane jako tabu. Wniosek taki nasuwa się na podstawie tzw. dopowiedzi pana Orlicza (sprowokowanej już po wywiadzie) o tym, że nie zawarł w zasadniczej części narracji sprawy rozwodu i opuszczenia córki, oraz wypowiedzi Szymona S., który opowiadając o powojennym poważnym konflikcie z bratem (AK - UB) stwierdza: „gdy to mówię, to nie mogę o tym mówić" [komuś? sobie? - J.T.].

Podobnie trudne do wyrażenia w słowach, określane jako ,zaskakujące” lub „niepojęte", „nie do wyobrażenia” jest spostrzegane przez narratorów opowiadających o swym pobycie w obozie koncentracyjnym wyjątkowe okrucieństwo niemieckich funkcjonariuszy w zestawieniu $\mathrm{z}$ ich rolami rodzinnymi. Mamy więc w materiałach pozostawione bez komentarza charakterystyczne przeciwstawienia z zawieszeniem głosu: pani Zofia z Ravensbrück - "biła (-)... a sama była w ciąży" (s. 18); pan Orlicz: ,... a on miał rodzinę gdzieś tam daleko... pod bombami amerykańskimi (-). A tu! potrafił zaszczuć człowieka" (s. 12). Byłoby to świadectwo uznania w tych narracjach związków rodzinnych za sytuację życiową o charakterze sacrum. Na rzecz takiej interpretacji rodziny w materiałach przemawia także to, że kategorie rodzinne używane metaforycznie ułatwiają narratorom określenie poczucia wyjątkowości wspólnoty z ludźmi, z którymi związały ich losy wojenne. Tak się dzieje, gdy opowiadania dotyczą partyzantki, obozu w Ravensbruck, wigilii w Starobielsku, szpitala w armii gen. Andersa czy ucieczki we wrześniu 1939 r. Wystarczy użyć słów - rodzina, braterstwo, aby odwołać się do pierwotnych uczuć więzi i pierwotnych uzasadnień bezwarunkowych świadczeń. „Te wieści z Polski przechodziły naszą imaginację. (-) Mieliśmy tam bliskich, śmiertelnie zagrożonych $i$ to nas wszystkich w jedną rodzinę łączyło jak nigdy" - pisze Czapski (1990: 348).

\section{6.}

I wreszcie, konieczność ochrony własnej wspólnoty rodzinnej, a co za tym idzie - własnej osoby, bywa używana przez Niemców jako argument ostateczny w chwili bezpośredniego zagrożenia życia. Sytuację tego typu znajdujemy w balladzie Adama Mickiewicza pt. Powrót taty:

... puszczajcie nas zdrowo,

Nie róbcie małych sierotami dziatek

I młodej małżonki wdową.

Dziatki sprawiły, że uchodzisz cało, 
Ach ja mam żonę! i u mojej żony

Jest synek taki maleńki.

Licząc na naturalne porozumienie w tej kwestii na mocy zasady przekładalności rodzinnych perspektyw żołnierze niemieccy skutecznie apelowali do przeciwnika w ostatniej fazie przegranej już wojny lub w chwili klęski w walce. Dla uwiarygodnienia swej roli męża czy ojca pokazywali noszone przy sobie rodzinne fotografie (Pan Stanisław, „córka kolejarza”). Również - jak wiadomo - to właśnie głośne wołanie więźnia skazanego na śmierć w Oświęcimiu o litość przez wzgląd na żonę i dzieci doprowadziło do ofiary ojca Maksymiliana Kolbego, esesmani zaś przystali na to niespodziewane zastępstwo.

W wywiadach znajdujemy dowody respektowania przez państwo niemieckie więzi rodzinnej Polaków: informacja o pobycie narratora w obozie jenieckim przesłana jego siostrom przez Niemiecki Czerwony Krzyż, informacje o miejscach pochówku poległych we wrześniu 1939 r. przesyłane ich rodzinom przez legalnie działający PCK, przekazanie synowi urny z prochami ojca z Mauthausen-Gusen, uwolnienie z łapanki matki i siostry na prośbę narratorki z „dobrymi” dokumentami.

Znajdujemy w narracjach również świadectwa brutalnego obchodzenia się $\mathrm{z}$ rodzinami. Lęk o to, aby własna rodzina nie była poddana represjom, wynikający z wiedzy o powszechnym stosowaniu przez okupantów odpowiedzialności zbiorowej, towarzyszy narratorom decydującym się na konspirację:

No, śmierć groziła pewna. I to jeszcze nie własna, a jeszcze rodziny, kogo tam. Bo w tym okresie, to co się czuło najbardziej, to nie własne życie (-). Liczyło się to, jak będą torturować, czy się wytrzyma. (-) To tego ja się strasznie bałem. Że mogę nie wytrzymać. Poza tym - rodzina. No. Niech się coś stanie, to rodzina od razu cała szła do obozu. No, takich było kilka przypadków" (s. 24).

Zadawanie człowiekowi śmierci na oczach jego bliskich uznawane jest za ekstremalne cierpienie i czyn zbrodniczy wywołujący najwyższe moralne oburzenie.

Podobne uczucie towarzyszy opowiadaniu dotyczącemu okupacji radzieckiej, gdy mówi się o rozdzieleniu członków rodziny sąsiadów narratora podczas wywózki na Wschód (p. Stanisław) lub o wykorzystywaniu więzi rodzinnej przy wydobywaniu informacji podczas śledztwa. Metody śledztwa zagrażające bliskim stosowane są również przez Niemców. Można stwierdzić, iż wysoko waloryzuje znaczenie powiązań rodzinnych ten, kto dopuszcza się używania ich jako środka szantażu albo wyrafinowanego sposobu zadawania cierpienia. Powszechność takich praktyk jest mocnym, acz tragicznym, argumentem na rzecz twierdzenia o ponadkulturowej elementarności układów rodzinnych. 
7.

Członkowie rodziny narratorów pełnią w opowiadaniach o wojnie jeszcze jedną godną podkreślenia funkcję. Narratorzy powołują się na nich jak na wiarygodnych świadków wydarzeń razem przeżytych lub takich, w których tamci brali udział. Można przypuszczać, że informacje przytaczane za kimś z rodziny są już często na różne sposoby zespołowo przepracowane, gdyż w rodzinach zdarzają się do dziś liczne okazje do rozmów o losach krewnych w czasie wojny (por. Pani Ewa, fragment wywiadu użyty przeze mnie jako motto). Są to poza tym często informacje jeszcze $\mathrm{z}$ tamtych czasów, a więc przyswojone przez narratorów w niezwykłym kontekście, podczas wojny bowiem ludzie zabiegali szczególnie o to, aby dowiedzieć się, co się dzieje z nieobecnymi w domu członkami rodzin. $\mathrm{Na}$ przykład Józef Czapski mówi o Powstaniu Warszawskim przeżywanym niejako zastępczo w osobie siostry:

Mam w ręku dziennik prowadzony z dnia na dzień siostry mojej Marii Czapskiej, która w Warszawie przeżyła pierwsze niemieckie oblężenie w 1939 r. Warszawy nie opuszczała i przeżyła tam także powstanie - w centrum stolicy. Jej krótkie notatki z dnia na dzień wówczas spisywane, ewokują więcej niż to, co bym mógł dzisiaj po latach powiedzieć. Włączam je częściowo do tego rozdziału (Czapski 1990: 373).

„Ja osobiście nie doznałem tych szykan, jakie wielu moich najbliższych doznało. Mianowicie już w 40 roku zaczęło się wysiedlanie ludności. I w maju 1940 r. został wysiedlony mój ojciec z drugą matką i przyrodnią siostrzyczką" - mówi pan Franciszek S.

\section{8.}

Na zakończenie poświęćmy uwagę wierszowi Juliana Tuwima Matka (1955: 222). Jest to autobiograficzne świadectwo poety dotyczące czasów wojny. W niezwykle skondensowany i wielowymiarowy sposób oddaje osobisty udział Tuwima w tragicznych losach wojennych jego matki, pani Adeli Tuwimowej. Dodajmy, że w czasie II wojny światowej Tuwima nie było w Polsce. Mieszkał w Stanach Zjednoczonych i Brazylii. Oto ten wiersz:

Matka

I

Jest na łódzkim cmentarzu,

Na cmentarzu żydowskim,

Grób polski mojej matki,

Mojej matki żydowskiej.

Grób mojej Matki Polki,

Mojej Matki Żydówki,

Znad Wisły ją przywiozłem, 
Na brzeg fabrycznej Łódki.

Głaz mogiłę przywalił, A na głazie pobladłym, Trochę liści wawrzynu, Które z brzozy opadły. A gdy wietrzyk słoneczny, Igra z nimi złociście, W Polonię, w Komandorię, Układają się liście.

II

Zastrzelił ją faszysta, Kiedy myślała o mnie, Zastrzelił ją faszysta, Kiedy tęskniła do mnie. Nabił - zabił tęsknotę, Znowu zaczął nabijać, Żeby potem... lecz potem Nie było już co zabijać. Przestrzelił świat matczyny: Dwie pieszczotliwe zgłoski, Trupa z okna wyrzucił $\mathrm{Na}$ święty bruk otwocki.

Zapamiętaj, córeczko! Przypomnij, późny wnuku! Wypełniło się słowo: „Ideał sięgnął bruku”.

Zabrałem ją z pola chwały, Oddałem ziemi - macierzy...

Lecz trup mojego imienia

Do dziś tam jeszcze leży.

W pierwszej części przez zastosowanie pisanych dużą literą pojęć w wyrażeniach ,grób mojej Matki Polki, mojej Matki Żydówki” syn mówiąc o matce włącza ją i siebie wraz z nią w specyficzne kulturowe uniwersum polskości poparte nazwami polskich orderów - Polonia, Komandoria. Adela Tuwimowa reprezentuje w ten sposób i symbolizuje wszystkie matki Polaków i Żydów zamordowane w kraju nad Wisłą w czasie II wojny światowej, on zaś jako jej syn - wszystkich Polaków i Żydów mających na cmentarzach groby swych matek.

Identyfikację z polskim dziedzictwem narodowym poprzez wzięte z Mickiewicza określenie Matka Polka, rozszerzonym o równoległe z nim - Matka Żydówka, pogłębia w części drugiej wiersza cytat z Fortepianu Szopena Norwida, oznaczający ekstremalną sytuację polskiej kultury zagrożonej przez okupanta.

Część druga wiersza dopełnia część pierwszą w wymiarze prywatnym, a zarazem uniwersalnym. Przedstawia scenę między zabójcą, matką i synem, 
wyodrębnionym poprzez imię z ogółu wszystkich ludzi. Osoby te tworzą układ jedyny i niepowtarzalny. Użyte przez poetę słowa umożliwiają wyrażenie poglądu, że zabicie osoby, która poprzez tęsknotę do swego syna i myśli o nim w ostatniej chwili życia jest przede wszystkim matką, to zabicie jednym strzałem nie tylko samej tej osoby, lecz całego matczynego świata, a w nim imienia syna, który do świata tego należy. Świat matczyny, owe „dwie pieszczotliwe zgłoski”, to zarówno słowo „mamo”, jak słowo „synku”, a także imię „Julku”. Nie można lepiej wyrazić istoty relacyjności stosunków i ról rodzinnych.

Tragiczne podobieństwo okoliczności wyrzucenia na bruk zwłok matki i fortepianu Szopena podkreślił Tuwim odwołując się do przejmujących słów kończących znany wiersz Norwida. Dzięki temu odwołaniu historycznie zlokalizowany gwałt dokonany w czasie II wojny światowej uzyskał ten sam uniwersalny wymiar, jaki osiągnął w swym utworze Norwid. Metafora „trup mojego imienia do dziś tam jeszcze leży" adekwatnie, jak się wydaje, odzwierciedla założoną przeze mnie na wstępie sytuację żywego doświadczania zbrodniczości wojny, dopóki narratorzy opowiadają o niej lokując się w rolach rodzinnych. W ślad za Norwidem wiersz Tuwima zawiera przesłanie, by za pomocą dalszych rodzinnych przekazów (córeczka, późny wnuk), pamięć o konsekwencjach wojny była utrwalona na długie lata.

Po wojnie syn spełnił powinność wobec zabitej matki. Zabrana przez syna z pola chwały matka znalazła swe miejsce spoczynku. Jest ono w wierszu oznaczone w części pierwszej jako łódzki cmentarz, cmentarz żydowski, grób polski, w części drugiej jako ziemia-macierz. Lecz obrządek nie został spełniony do końca. Przez obraz trupa własnego imienia do dziś leżącego na ulicy w Otwocku poeta odwołuje się do archetypalnej sytuacji z Antygony. Niepogrzebany trup brata, którego pozbawiono życia w bratobójczej wojnie, jest obrazą boską wymagającą od najbliższej krewnej - od siostry - przywrócenia sakralnego porządku pogwałconego przez prawa ludzkie. Lecz jak pogrzebać zabite imię? Kto jest w stanie to zrobić? ${ }^{1}$ Słowa ostatniej zwrotki wiersza są najsilniejszym oskarżeniem wojny jako sytuacji nieludzkiej i gwałcącej naturalny porządek świata.

Na koniec zauważmy, że zabójca jest identyfikowany w tej wieloznacznej wypowiedzi jedynie jako faszysta, bez żadnych odniesień etnicznych. Wobec wielu antyniemieckich tekstów Juliana Tuwima ma to swoją szczególną wymowę.

Cóż dodać po tym wierszu w kwestii elementarnych identyfikacji rodzinnych zawartych $\mathrm{w}$ polskich doświadczeniach wojennych?

1 Przypomnijmy swoisty pomnik imion stojący na terenie dawnego Umschlagplatzu przy ul. Stawki w Warszawie. 


\section{Bibliografia}

Czapski J., 1990, Na nieludzkiej ziemi, Czytelnik, Warszawa.

Eisenstadt S., Giesen B., 1993, The Construction of Collective Identity, "Archives

Européennes de Sociologie XXVI (1), s. 72-102.

Łukasiewicz P., 1989, Funkcje domu w okresie okupacji niemieckiej, „Kultura i Społeczeństwo", nr 2, s. 67-82.

Mickiewicz A., 1975, Wiersze, Czytelnik, Warszawa.

Miller M., 1993, Arystokracja, Tenten.

Silverman D., 1993, Interpreting Qualitative Data, Sage Publication, London.

Strzembosz T., 1993, Bohaterowie „Kamieni na szaniec” w świetle dokumentów,

Państwowe Wydawnictwo Naukowe, Warszawa.

Tuwim J., 1955, Wiersze, Czytelnik, Warszawa.

Tyszka A., 1993, Kultura jest kultem wartości, Norbertinum, Lublin.

Tyszka Z., 1984, Rodzina a struktura społeczna, Pomorze, Bydgoszcz.

Wańkowicz M., 1991, Ziele na kraterze, Elipsa, Warszawa. 